\title{
A járványügyi veszélyhelyzet megélése a próbaidős tiszthelyettesek körében
}

\section{BORBÉLY Zsuzsanna ${ }^{1}$}

\begin{abstract}
2020-ban hódító körútra indult a világban a koronavírus-járvány. Erre tekintettel a 2019-2020-as tanévben próbaidős évüket töltő tiszthelyettesek körében egy folyamatban levő kutatás részeként felmérték a veszélyhelyzet első két hónapjának megélését, tapasztalatait, hiszen a rendőri állomány tagjaiként a mindennapi feladatellátásukban szerepet kaptak a veszélyhelyzethez kapcsolódó tevékenységek.

A vizsgálatot egy általunk összeállított, 14 kérdésből álló minikérdőivként integrálták a kutatásban használt kérdőívcsomagba. A lekérdezés online formában történt, a szakmai vizsgák időszakában (2020. május vége - június eleje), s összesen 28 fö töltötte ki a koronavírus miatt kialakult járványhelyzettel kapcsolatos kérdöívet.

A válaszadók körében a hatósági házi karantén ellenőrzése, a határátkelöhelyeken ellátott szolgálat és a kijárási korlátozásokkal kapcsolatos közterületi szolgálat is megjelent feladatként. A válaszadók döntő többsége (85,7\%) nem érezte érzelmileg megterhelőbbnek ezen időszak feladatellátását. Fizikálisan ugyanakkor valamivel többen értékelték megterhelőbbnek a szolgálatokat (28,6\%). A mintában a legintenzívebb félelemként a családtag fertőzötté válása jelentkezett, ezt követte mások megfertőzése és a kollégák megfertőződése - saját megfertőződésüktől jelentősen kevésbé féltek.

Az eredmények alapján valószínűsithető, hogy a veszélyhelyzet első két hónapjában a próbaidős állomány számára nem jelentett kiemelkedő pszichés terhelést a járványügyi veszélyhelyzethez kapcsolódó feladatok ellátása. Habár az eredmények nem reprezentatívak, de kiindulási alapot jelenthetnek a további vizsgálatok számára, mivel a téma mindenképpen érdemes további kutatásra - különösen, hogy az őszi járványügyi helyzet jelentősen megterhelöbb mindenki számára mentálisan és fizikálisan egyaránt.
\end{abstract}

Kulcsszavak: koronavírus, érzelmi megterhelés, próbaidős állomány

Borbély Zsuzsanna alapellátó pszichológus, Repülőtéri Rendőr Igazgatóság; doktori hallgató, Nemzeti Közszolgálati Egyetem Rendészettudományi Doktori Iskola.

Zsuzsanna Borbély Police Psychologist, Airport Police Directorate; PhD student, University of Public Service, Doctoral School of Police Sciences and Law Enforcement.

E-mail: Borbely.Zsuzsanna@uni-nke.hu, ORCID: https://orcid.org/0000-0001-7197-832X 


\section{Bevezetés}

Az alábbiakban röviden áttekintem a koronavírus 2020. tavaszi hulláma kapcsán a rendvédelmi szempontból fontos momentumokat, a koronavírus által okozott veszélyhelyzet mentális egészségre gyakorolt hatásait, valamint a próbaidős állománynyal kapcsolatos néhány tudnivalót.

\subsection{Koronavírus és a rendöri munka}

2020-ban nagyon sok minden változott az életünkben a koronavírus-járvány következtében. Januárban először csak a hírek szállingóztak Kínából egy rejtélyes, gyorsan terjedő, új betegségről, a koronavírusról, majd pár nappal-héttel később már az apokaliptikus hangulatú képek is érkeztek a karantén alá vont városokból. Februárban a koronavírus már Olaszországban szedte áldozatait, majd március 11-én hazánkban is kihirdették a veszélyhelyzetet. Szintén aznap látott napvilágot a 41/2020. (III. 11.) Korm. rendelet, ${ }^{2}$ amelyben már megjelentek olyan intézkedések, amelyek a rendőri állomány feladataival kapcsolatosak voltak. Ez már jól jelezte azt, hogy a járványhelyzet kezelésében a rendvédelmi szerveknek hazánkban is komoly feladataik lesznek - mint ahogyan azt a más országokból érkező hírekből korábban már láthattuk-hallhattuk. Világszerte bevetették a rendőri erőket a lezárások, karantén és kijárási korlátozások betartatása érdekében, ${ }^{3}$ nem volt tehát meglepő, hogy ez Magyarországon is megtörténik. Ezt követően fokozatosan egyre több minden változott meg a rendőri állományt és a munkavégzéshez kapcsolódó szabályokat érintően. Erre példa az intézkedések során a szociális távolságtartás intézményére vonatkozó szabályok, illetve a védőfelszerelések (szájmaszk, gumikesztyű, kézfertőtlenítő) használata. ${ }^{4}$ Emellett nem csupán a rendőröket általánosságban érintő szabályok terén, hanem az egyes szakterületek tevékenysége tekintetében is voltak változások, amelyek mértéke szakterületenként eltérő volt. ${ }^{5}$

41/2020. (III. 11.) Korm. rendelet az élet- és vagyonbiztonságot veszélyeztető tömeges megbetegedést okozó humánjárvány megelőzése, illetve következményeinek elhárítása, a magyar állampolgárok egészségének és életének megóvása érdekében elrendelt veszélyhelyzet során teendő intézkedésekről.

3 Kathryn Farrow: Policing the pandemic in the UK using the principles of procedural justice. Policing: A Journal of Policy and Practice, 14. (2020), 3, 587.

4 Wesley G. Jennings - Nicholas M. Perez: The immediate impact of COVID-19 on law enforcement in the United States. American Journal of Criminal Justice, 45. (2020), 690-701.; Farrow (2020) i. m.; John Stogner - Bryan Lee Miller - Kyle McLean: Police stress, mental health, and resiliency during the COVID-19 pandemic. American Journal of Criminal Justice, 45. (2020), 718-730.; Pawan Arun Khadse et alii: Mental health impact of COVID-19 on police personnel in India. Indian Journal of Psychological Medicine, 42. (2020), 6. 580-582.

5 Jennings-Perez (2020) i. m.; Stogner-Miller-McLean (2020) i. m. 


\subsection{A koronavírus okozta mentális terhelés}

A koronavírus-járvány kirobbanásának kezdete óta folyamatosan kutatják a vírus és a járvány hatásait az életünk minden területére, így a mentális egészségre gyakorolt hatásait is. Tekintettel arra, hogy járványügyi veszélyhelyzetről van szó, nem meglepő, hogy a vonatkozó kutatások egyik fő fókuszában az egészségügyi személyzet áll, de emellett szép számmal találhatunk publikációkat a rendőrökre, illetve az átlagpopulációra vonatkozóan is. Ezek tapasztalatai összefoglalóan elmondható, hogy a szorongásos betegségek egyértelmú növekedése mellett a stressz szintje, illetve a depresszív tünetek arányának emelkedése is több országban megjelent. ${ }^{6}$

A rendvédelmi személyzetre koncentráló kutatásokat áttekintve elmondhatjuk, hogy az eredmények döntően egy irányba mutatnak. Kínában a járvány kapcsán elhíresült Vuhanban és környékén végeztek online felmérést a rendőrök körében, amelyben különböző szintủ szorongást és depressziót találtak. Eredményeik szerint az iskolai képzettség szintje, a konkrét lakóhely (körzet), a rendőri munka szakterülete (bűnügyi, közlekedési, közrendvédelmi stb.) és az altató használata rizikófaktoroknak bizonyultak a szorongás és depresszió szempontjából.7 Indiában több kutatás is készült a témában. Grover és munkatársai szintén online kutatás keretében emelkedett stressz-szintet és negatív érzelmi válaszokat találtak, emellett a női rendőrök magasabb szintû szorongásról, depresszióról és negatív érzelmi állapotokról számoltak be. ${ }^{8}$ Khadse és munkatársai tanulmánya szintén felhívja a figyelmet a Covid-19 által okozott rendőri kihívások negatív pszichés hatásaira, illetve jelzi, hogy a rendőrök körében magasabb volt a vizsgált időszakban a fertőzöttségi ráta, mint az átlagpopulációban. ${ }^{9}$

Oroszországban Soloviev és munkatársainak kutatása azt találta, hogy a moszkvai női rendőrök a Covid-19 időszakában teljesített szolgálataik alatt jobban alkalmazkodtak a stresszteli szituációkhoz, de magasabb szintű szorongásról és depresszióról számoltak be. ${ }^{10}$

Frenkel és munkatársai kutatása kifejezetten az európai rendőrökre koncentrált a Covid-19 tavaszi időszakában, longitudinális vizsgálatban. Hat európai ország rendőri körében zajlott a vizsgálat: Ausztria, Németország, Svájc, Hollandia és Spanyolország baszk régiója. Eredményeik több érdekességet is tartogattak. Azon kevesek körében,

Sandeep Grover et alii: Psychological impact of COVID-19 lockdown: An online survey from India. Indian Journal of Psychiatry, 62. (2020b), 4. 354-362.; Angel Vicario-Merino - Noemi Muñoz-Agustin: Analysis of stress, anxiety and healthy habits in the Spanish COVID-19 confinement. Health Science Journal, 14. (2020), 2. 1-6.

7 Lili Yuan et alii: A Survey of psychological responses during the coronavirus disease 2019 (COVID-19) epidemic among Chinese police officers in Wuhu. Risk Management and Healthcare Policy, 13. (2020), 2689-2697.

8 Sandeep Grover et alii: Psychological impact of COVID-19 duties during lockdown on police personnel and their perception about the behavior of the people: An exploratory study from India. International Journal of Mental Health and Addiction, (2020a), 1-12.

9 Khadse et alii (2020) i. m.

10 Andrey Soloviev - Sergey Zhernov - Elena Ichitovkina: Female Moscow police officers' emotional reactions features during service in the COVID-19 pandemic emergency conditions. Journal of Biomedical Research \& Environmental Sciences, 1. (2020), 6. 213-215. 
akik beszámoltak a magánéleti stresszorokról, alapvetően a hozzátartozókért való aggodalom és az online oktatás miatt otthonról tanuló gyerekek felügyelete okozta a stresszt. A főbb rendőri feladatok ebben az időszakban a megszokottak mellett a koronavírushoz kapcsolódó rendőri tevékenységek voltak. A munkahelyi stressz megtapasztalása a járványhoz kapcsolódóan nagyon vegyes képet mutatott: a válaszadók mintegy negyede nem vett észre változást ezen a téren, ugyanakkor a fertőzéshez kapcsolódó félelmek közül ebben a kutatásban is több aspektus megmutatkozott: a fertőzötté válástól való félelem, illetve a mások megfertőzésére irányuló aggodalmak. Emellett a munkahelyi stresszorok körében megjelentek még a vizsgált időszakban rendkívül gyorsan változó jogszabályi környezet okozta kihívások is, illetve a kollégák közti szociális távolságtartás elvárása. Foglalkoztak a védőfelszerelések kérdésével, ennek kapcsán nagyon megoszlottak az egyes nemzetiségek rendőri tapasztalatai - míg egyes országokban voltak időszakok, ahol a rendőröknek sem jutott belőlük elég, addig máshol bőségesen rendelkezésre állt. Összességében rendkívül érdekes és sokrétủ vizsgálatot sikerült lefolytatniuk a vírus európai terjedésének kezdeti hónapjaiban, amely a rendőröktől kvalitatív adatokat (személyes élményeket) is összegyűjtött az egyes kérdéskörök kapcsán. ${ }^{11}$

Nagy-Britanniában Laufs és Waseem szisztematikus áttekintést tett közzé, amelyben a korábbi közegészségügyi vészhelyzetekkel vagy katasztrófákkal kapcsolatos kutatások rendőri szempontból releváns eredményeit foglalta össze. Négy nagy témakör - a rendőri kommunikáció, a pszichés egészség és jóllét, a szervezeten belüli hatások dinamikája és a különböző szervek közötti együttmúködések és ezek koordinációja - mentén összegzi a meglevő tudásanyagot, s ajánlásokat fogalmaz meg arra nézve, hogy a Covid-19 időszakában mire lenne érdemes figyelni és törekedni ezeket illetően. ${ }^{12}$

\subsection{A próbaidös tiszthelyettesi állomány}

A rendőr tiszthelyettesek képzése hazánkban többféle képzési formában történik. Az elmúlt években jellemzően a kétéves képzés második évében iskolai tanulmányaik mellett próbaidős tiszthelyettesként teljesítenek szolgálatot különböző rendőri szervek (Készenléti Rendőrség, Budapesti Rendőr-főkapitányság, megyei rendőr-főkapitányságok, Repülőtéri Rendőr Igazgatóság) állományában. ${ }^{13}$

A képzés alapvetően moduláris formában zajlik, az első tanévben döntően iskolai képzésben vesznek részt, míg a második tanévben már a képzési idejük közel felét

11 Marie Ottilie Frenkel et alii: The impact of the COVID-19 pandemic on European police officers: Stress, demands, and coping resources. Journal of Criminal Justice, 72. (2020), 1-14.

12 Julian Laufs - Zoha Waseem: Policing in pandemics: A systematic review and best practices for police response to COVID-19. International Journal of Disaster Risk Reduction, 51. (2020), 1-17.

13 Borbély Zsuzsanna: Az iskolarendszerủ rendőrképzés napjainkban. In Zsámbokiné Ficskovszky Ágnes (szerk.): Biztonság, szolgáltatás, fejlesztés, avagy új irányok a bevételi hatóságok müködésében. Budapest, Magyar Rendészettudományi Társaság Vám- és Pénzügyőri Tagozat, 2019. 38-51. 
gyakorlati helyükön töltik. A képzésre jelentkezők jelentékeny hányada közvetlenül érettségi után kezdi meg tanulmányait, de mindig találhatunk 30 év körüli-feletti tanulót ebben a képzési formában is. Ennek megfelelően nagyon fiatal átlagéletkorú csoportokról beszélhetünk. ${ }^{14}$

A próbaidős tiszthelyettesek, akik 2019 szeptemberétől kezdték próbaidős évüket, párhuzamosan képzésük második évével, 2020 tavaszán szolgálatteljesítésük során a rendőri állomány tagjaként részeseivé váltak a veszélyhelyzeti időszak szolgálatainak is. A kétéves rendőr tiszthelyettesi képzésben részt vevők esetében ez a szakmai vizsgákat megelőző mintegy két hónapos időszakot foglalta magában. Mindezek révén tehát részt vettek a 2020. tavaszi járványügyi veszélyhelyzet idején az ehhez kapcsolódó különböző feladatokban szolgálataik során: a kijárási korlátozásokhoz kapcsolódóan a közterületi tevékenységben, karantén-ellenőrzésekben, illetve a határzár miatt a határrendészeti tevékenységekben. ${ }^{15}$

\subsection{Problémafelvetés}

A jövőbeni hasonló helyzetekben történő feladatellátásra való pszichés felkészítés érdekében érdemesnek találtuk felmérni, hogy a próbaidős állomány milyen jellegű élményekkel, tapasztalatokkal gazdagodott, s esetlegesen egészségmagatartási szokásaikban milyen változások következtek be ebben az időszakban.

\section{Módszer}

A koronavírus okozta egészségügyi veszélyhelyzetben végzett rendőri tevékenységhez kapcsolódó alábbi felmérést egy iskolarendszerű képzésben részt vevő, próbaidős tiszthelyettes-állomány egészségmagatartási szokásait, mentális egészségét és munkahelyi stresszel kapcsolatos megélését vizsgáló longitudinális kutatás záró mérföldköveként végzett kérdőíves mérés részeként végeztük el.

\subsection{Vizsgálati személyek}

Az egyik (a vizsgálat időpontjában még) ${ }^{16}$ rendészeti szakgimnázium 2020 májusjúniusában szakmai vizsgát tevői körében készült a felmérés. A kutatásban való

\footnotetext{
Borbély (2019) i. m. 39-44.

Jennings-Perez (2020) i. m.; Stogner-Miller-McLean (2020) i. m.

2020. július 1-jétől a korábbi négy rendészeti szakgimnázium közül kettő rendvédelmi technikummá, kettő pedig a Rendőrképző Akadémia két helyszínévé vált.
} 
részvétel önkéntes és anonim volt, a részvételt megelőzően tájékoztatásra került sor, és a kérdőív kitöltése bármikor szabadon befejezhető volt. ${ }^{17}$

A kérdőív kitöltése online formában történt, tekintettel az érvényben levő szociális távolságtartásra vonatkozó szabályokra. Mintegy 100 fő számára küldtük ki az online kérdőív elérhetőségét, közülük 28 fő töltötte ki a koronavírussal kapcsolatos blokkot. Ez meglehetősen alacsony kitöltési arány, a minta így nem reprezentatív. A kutatás anyagaiba kizárólag a kutatást végző személy nyerhet betekintést.

Tehát 28 fő vállalta a vizsgálat e részében való részvételt. A minta átlagéletkora 23,14 év ( \pm 5,52 év), a legfiatalabb válaszadó 20 éves, a legidősebb 42.

\subsection{A kérdôiv felépitése}

A koronavírussal kapcsolatos blokk a kutatási kérdőívcsomag utolsó kérdéscsoportjaként szerepelt, munkahelyi stresszre, kiégésre, mentális egészségre és egészségmagatartási szokásokra vonatkozó kérdéssorokat követően. Jelen írásban a Covid-19-járványhelyzet kezeléséhez kapcsolódó kérdések ismertetésére szorítkozom, tekintettel arra, hogy az alábbiakban csak az ezzel kapcsolatos eredményeket mutatom be (terjedelmi okokból). A továbbiakban ezért kizárólag ez a blokk értendő a kérdőív alatt.

A szociodemográfiai adatok tekintetében az életkort, nemet, családi állapotot, lakóhelyet, illetve a próbaidő helyét vontuk be a kérdőívcsomagból.

A kérdőív a következő témaköröket érintette:

- részt vett-e a járványhelyzettel kapcsolatos rendőri tevékenységben; ${ }^{18}$

- milyen típusú feladatokban vett részt, ${ }^{19}$ mennyire érezte megterhelőnek ezen feladatot/feladatokat; ${ }^{20}$

- szolgálati hely távolsága a lakóhelytől, ezzel kapcsolatosan szállás igénybevétele, azzal való elégedettség; ${ }^{21}$

- szolgálat átlagos időtartama;

- védőfelszerelésekkel kapcsolatos kérdések; ${ }^{22}$

- félelem különböző helyzetektől; ${ }^{23}$

\footnotetext{
17 A koronavírus okozta járványügyi veszélyhelyzettel kapcsolatos rendőri tevékenységek kérdéskörét egy folyamatban levő longitudinális kutatás utolsó adatfelvételi időpontjában vettük fel, az addigiakban is használt kérdőívcsomag kiegészítéseként. A kutatás minden mérési pontja előtt a résztvevők tájékoztatásban részesültek a kutatás témáját, az adatkezelést és az eredmények felhasználását illetően, és beleegyező nyilatkozatot töltöttek ki.

18 Válaszlehetőségek: igen-nem.

19 Válaszlehetőségek: kijárási korlátozással kapcsolatos közterületi feladatok; karantén-ellenőrzés, határzár mentén történő feladatellátás.

20 A válaszadásra egy ötfokú skálán volt lehetőség, ahol az 1 az „egyáltalán nem érezte megterhelőnek”, míg az 5 a „nagyon megterhelőnek érezte" volt.

21 Ötfokú Likert-skálán történt a válaszadás, ahol az 1 = teljes mértékben elégedetlen, 5 = teljes mértékben elégedett volt.

22 Rendelkezésre állt-e, illetve elégedett volt-e a minőségével - utóbbi megítélése szintén ötfokú skálán történt.

23 A válaszadás ötfokú skálán történt, 1 = egyáltalán nem féltem, 5 = nagyon féltem tőle.
} 
- milyen mértékủ változásokat tapasztalt magán a megadott szempontok mentén, ${ }^{24}$ ezek mennyire befolyásolták a szolgálatellátást; ${ }^{25}$

- mennyire érezte megterhelőnek a szolgálatellátást a megadott szempontok szerint; ${ }^{26}$

- mennyire változott meg az egészséggel kapcsolatos viselkedése a megadott szempontok mentén. ${ }^{27}$

A kérdéssor összeállítása 2020. április végén történt, a saját munkahelyemen szerzett tapasztalatok nyomán, illeszkedve a longitudinális kutatás témájához.

Az elemzések során a Likert-skálán megválaszolandó kérdések esetében átlagés szórásértékeket számítottam ki, ezek eredményeinek összehasonlítására korrelációs elemzések készültek, emellett bizonyos csoportosítások mentén t-próbát végeztem el.

\section{Eredmények}

Az alábbiakban a kérdéscsoportok mentén először a leíró statisztikai eredményeket, majd pedig egyes kérdések kapcsán az összehasonlítások eredményeit foglalom össze.

\subsection{Szociodemográfiai adatok}

A minta nemi összetételét tekintve 17 fő válaszadó (60,71\%) férfi, 11 fő nő (39,29\%).

A családi állapotot tekintve 9 fő (32,14\%) egyedülállónak, 18 fő (64,29\%) stabil párkapcsolatban élőnek, míg 1 fő (3,57\%) házasnak vallotta magát. Az állandó lakóhely terén 6 fő (21,43\%) megyeszékhelyen vagy megyei jogú városban él, 6 fő $(21,43 \%)$ más vidéki városban, míg a fennmaradó 16 fő (57,14\%) faluban vagy községben.

A próbaidős évben a válaszadók 75\%-a (21 fő) valamely megyei rendőr-főkapitányság állományában teljesítettek szolgálatot (alapvetően a Dunántúlon), 21,43\% (6 fő) a Budapesti Rendőr-főkapitányság állományában, illetve 1 fő (3,57\%) a Repülőtéri Rendőr Igazgatóság állományának tagja.

\footnotetext{
24 A válaszadás négyfokú skálán történt, lehetséges értékek: 1 = nem változott, 2 = néha, 3 = gyakran, 4 = rendszeressé vált.

25 Ötfokú Likert-skála, 1 = egyáltalán nem befolyásolta, 5 = teljes mértékben befolyásolta.

26 Szempontok: érzelmileg és fizikálisan, lehetséges válaszok: igen/nem.

27 A válaszadás ötfokú Likert-skálán történt, szélsőértékek: 1 = egyáltalán nem jellemző rám, 5 = teljes mértékben jellemző rám.
} 


\subsection{Szolgálatteljesítés a tavaszi veszélyhelyzet idején}

A Covid-19 okozta járványhelyzethez kapcsolódóan a kérdőívben megjelölt feladattípusokban való részvétel aránya a következőképpen alakult március 11-től a szakmai vizsgára felkészítésre visszarendelésig: hatósági házi karantén ellenőrzésében 19 fő vett részt, a határátkelőhelyeken 12 fő teljesített, a kijárási korlátozással kapcsolatos közterületi tevékenységeket 27 fő látott el.

A válaszadók többsége, vagyis 64,29\% (18 fő) két feladatban, emellett 14,29\% (4 fő) egyetlen feladattípus kapcsán, illetve 21,43\% (6 fő) mindhárom feladatban részt vett.

Azt illetően, mennyire érezték megterhelőnek e tevékenységek ellátását, a válaszok átlaga 2 (szórás: 0,92) volt, vagyis elmondhatjuk, hogy a válaszadók nem érezték különösebben megterhelőnek ezeket a szolgálati feladatokat.

A szolgálati hely lakóhelytől való távolságát tekintve előrebocsátandó, hogy a vizsgálati minta esetében nem történt radikális átvezénylés a járvány hatására. A válaszok a következőképpen alakultak: 15 fő (53,57\%) 1-25 km-re, 4 fő (14,29\%) 26-50 km-re, 2 fő (7,14\%) 51-100 km-re, míg 6 fő (21,43\%) 201-250 km-re él szolgálati helyétől. Azok esetében, akik lakhelye nagy távolságra, vagyis több, mint 200 km-re volt szolgálati helyétől, lehetőségük volt szállás igénybevételére. Körükben a szállással való elégedettség értéke egy ötfokú skálán 2,67 $( \pm 1,51)$ volt, vagyis elégedettek is voltak, meg nem is annak színvonalával.

Egy szolgálat átlagos időtartama 12,54 ( $\pm 2,47)$ óra volt, a legrövidebb 8 órás, a leghosszabb 24 órás volt. A döntő többség 12 órás szolgálatokról számolt be.

A szolgálati helyen alapvetően rendelkezésre álltak az alapvető védőfelszerelések, azaz a szájmaszk, a gumikesztyú és a kézfertőtlenítő. Szintén megkérdezték azt is, hogy mennyire elégedettek ezekkel egy ötfokú skálán, ennek eredményét az 1. táblázat mutatja.

1. táblázat: A védőfelszerelésekkel kapcsolatos elégedettség átlag-és szórásértékei. Forrás: a szerző saját kutatása

\begin{tabular}{lcc}
\hline \multirow{2}{*}{ Védőfelszerelés } & \multicolumn{2}{c}{ elégedettség mértéke } \\
\cline { 2 - 3 } & átlag & szórás \\
\hline szájmaszk & 3,25 & 1,46 \\
\hline gumikesztyű & 3,14 & 1,48 \\
\hline kézfertőtlenítő & 3,21 & 1,55 \\
\hline
\end{tabular}

Vagyis a védőfelszerelések e három típusával körülbelül hasonló, közepes mértékben voltak elégedettek a vizsgálat résztvevői. 


\subsection{Egészségmagatartási szokások, mentális egészség a járványhelyzet idején}

A fertőzéssel kapcsolatos félelemérzet több csoportja volt jelen az állomány körében (ahogy tapasztalataim szerint a civil lakosság körében is): a fertőzöttel történő találkozás, a megfertőződéstől való félelem, a családtagjai közül fertőződik meg valaki, kollégája válik fertőzötté, illetve a válaszadó maga fertőz meg másokat. A félelem mértékét szintén egy ötfokú skálán kellett értékelnie a válaszadóknak. Az átlagértékek alapján kialakult sorrendet az átlagokkal és szórással együtt a 2. táblázat mutatja.

2. táblázat: Az egyes félelmek átlag- és szórásértékei, illetve az ezek alapján kialakult sorrend. Forrás: a szerző saját kutatása

\begin{tabular}{clcc}
\hline \multirow{2}{*}{ sorsz. } & \multicolumn{3}{c}{ félelem } \\
\cline { 2 - 4 } & típusa & átlaga & szórás \\
\hline 1. & családjában valaki megfertőződik & 3,75 & 1,43 \\
\hline 2. & ö fertőz meg másokat & 3,00 & 1,47 \\
\hline 3. & kollégája megfertőződik & 2,39 & 1,20 \\
\hline 4. & ő is megfertőződik & 1,96 & 1,00 \\
\hline 5. & fertőzöttel találkozik & 1,82 & 1,09 \\
\hline
\end{tabular}

A fentebbi táblázatból jól látható, hogy a válaszadók legerősebb félelme az volt a tavaszi időszakban, hogy a családjukban válik valaki Covid-19-fertőzötté. Ezt követte a válaszadó által mások megfertőzése, majd a kolléga fertőzötté válása. Az első hely esetében egy már konkrét, jelen levő félelemről beszélhetünk, a második hely esetében egy fél is, meg nem is típusú, nem túl intenzív félelemről, a továbbiak esetében pedig az inkább vagy egyáltalán nem fél tőle szintről beszélhetünk.

Az elmúlt mintegy két-három hónapra vonatkozóan egy négyfokú skálán kellett megítélniük a válaszadóknak, hogy milyen mértékben tapasztalták magukon a felsoroltakat, mennyire vettek észre magukon változásokat ezeket illetően. A válaszok átlagértékeit tekintve az aggódás megtapasztalása terén történt minimálisnak mondható változás, a többi esetében még kevésbé volt jelentős ennek mértéke. Az átlagokat és szórásokat a 3. táblázat mutatja.

3. táblázat: Az elmúlt időszakban megtapasztalt változások. Forrás: a szerző saját kutatása

\begin{tabular}{lrc}
\hline \multicolumn{1}{c}{ Önmagán megfigyelt változások } & átlag & szórás \\
\hline alvási nehézségeim voltak & 1,36 & 0,73 \\
fáradékonyabb lettem & 1,33 & 0,55 \\
ingerültté, feszültté váltam & 1,39 & 0,69 \\
megváltozott a viselkedésem másokkal szemben & 1,14 & 0,36 \\
türelmetlenebb lettem & 1,32 & 0,67 \\
aggódtam & 1,71 & 0,76 \\
állandóan a vírus körül forogtak a gondolataim & 1,39 & 0,63 \\
\hline
\end{tabular}




\begin{tabular}{|c|c|c|}
\hline \multicolumn{3}{|l|}{ Szolgálatellátást befolyásoló tényezők } \\
\hline alvási nehézségek & 1,46 & 0,88 \\
\hline fáradtság & 1,75 & 0,97 \\
\hline ingerültség, feszültség & 1,79 & 1,20 \\
\hline aggodalmaim a családom miatt & 2,67 & 1,52 \\
\hline állandóan a vírus körül forgó gondolataim & 1,41 & 0,69 \\
\hline félelem a fertőzötté válástól & 1,82 & 1,19 \\
\hline egyéb & 1,20 & 0,41 \\
\hline \multicolumn{3}{|l|}{ Egészségmagatartás szokások változásai } \\
\hline Kevesebb alkalommal edzettem. & 2,75 & 1,40 \\
\hline Gyakrabban fogyasztottam alkoholt. & 1,39 & 0,63 \\
\hline Egészségesebben étkeztem. & 2,43 & 1,10 \\
\hline $\begin{array}{l}\text { Több cigarettát szívtam el egy nap alatt, mint } \\
\text { korábban. }\end{array}$ & 1,25 & 0,59 \\
\hline $\begin{array}{l}\text { Több alkoholt fogyasztottam el egyszerre, mint } \\
\text { korábban. }\end{array}$ & 1,25 & 0,65 \\
\hline $\begin{array}{l}\text { Rövidebb időtartamban tudtam csak edzeni, } \\
\text { mint korábban. }\end{array}$ & 2,46 & 1,45 \\
\hline
\end{tabular}

A szolgálatellátás érzelmi, illetve fizikálisan megterhelő voltára külön is rákérdeztem ebben a részben: érzelmileg mindössze 14,29\% (4 fö), fizikálisan már 28,57\% (8 fő) ítélte megterhelőbbnek a veszélyhelyzet időszakában a szolgálat ellátását.

A veszélyhelyzet kihirdetése óta a szolgálatellátás kapcsán egyes tényezők befolyásoló voltát is megkérdeztük, ezeket egy ötfokú skálán értékelték a válaszadók. Ezeket illetően a 3. táblázat mutatja az egyes tényezők kapcsán a résztvevők átlagait és a szórásokat.

Utolsó kérdésként az egészséggel kapcsolatos viselkedés változásait értékelték a válaszadók. Az egyes tételeket, illetve a hozzájuk kapcsolódó átlagértékeket, illetve szórásmutatókat a 3. táblázat mutatja.

Az edzéssel és táplálkozással kapcsolatos kérdések hasonló átlagokat értek el, mint ahogyan a dohányzásra és alkoholfogyasztásra vonatkozó állítások is. A legmagasabb átlagértékkel a kevesebb edzés állt, legalacsonyabb értékkel a dohányzáshoz, alkoholfogyasztáshoz kapcsolódó kérdések szerepeltek, ugyanakkor ezen átlagértékek sem érik el a közepes mértéket az ötfokú válaszskálán.

\section{4. Összehasonlító vizsgálatok}

Összehasonlítottam a koronavírus okozta járványhelyzet kapcsán végzett rendőri tevékenység megterhelő voltára vonatkozó eredményt, valamint a kifejezetten mentális és fizikális megterhelésre vonatkozó kérdések kapcsán kapott eredményeket t-próba alkalmazásával. Sem a mentális, sem a fizikális megterhelés kapcsán nem lett szignifikáns az eredmény. 
A félelmekre vonatkozó tételek esetében korrelációs eljárást alkalmazva hasonlítottam össze az egyes tételek egymáshoz való viszonyulását. Az eredményeket a 4. táblázat mutatja.

4. táblázat: Az egyes félelmekre vonatkozó tételek korrelációja $\left({ }^{*} p \leq 0,05 ;{ }^{* *} p \leq 0,01\right)$.

Forrás: a szerzó saját kutatása

\begin{tabular}{llcccc}
\hline Félelmek & a) & b) & c) & d) & e) \\
\hline a) & fertőzöttel találkozik &, $538^{* *}$ &, 089 &, $595^{* *}$ &, 232 \\
\hline b) & ő is megfertőződik & &, $434^{*}$ &, $415^{*}$ &, $379^{*}$ \\
\hline c) & családjában valaki megfertőződik & & &, $384^{*}$ &, $724^{* *}$ \\
\hline d) & kollégája megfertőződik & & &, $612^{* *}$ \\
\hline e) & ő fertőz meg másokat & & & \\
\hline
\end{tabular}

Mint az látható, több esetben is szignifikáns együttjárás mutatkozott az egyes tételek között, ezek értéke döntően közepes, amely jelentős kapcsolatra utal. A fertőzöttel való találkozás a saját megfertőződés és a kolléga megfertőződése tételekkel mutatott statisztikailag jelentős kapcsolatot. A válaszadó saját megfertőződésétől való félelme a fertőzötté váló családtagtól, a kolléga megfertőződésétől, illetve a válaszadó által történő fertőzéssel közepes erősségű együttjárást mutatott. A családtag megfertőződése a kolléga megfertőződésével közepes, míg a válaszadó általi fertőzéssel erős kapcsolatot mutatott. A kolléga megfertőződése a válaszadó által történő fertőzéssel mutatott a fentebbieken kívül erős kapcsolatot. Nem meglepő módon a legerősebb kapcsolat a válaszadó általi fertőzés és a hozzá közelállók (család, kolléga) fertőzötté válása között mutatkozott, ezt követte erősségben a fertőzöttel való találkozás, valamint a válaszadó, illetve kollégájának megfertőződése között mutatkozó kapcsolat. Ezek az eredmények a munkából fakadó kockázatokon alapuló félelmek jelenlétére utalnak.

$\mathrm{Az}$ 5. táblázat a szolgálatellátást befolyásoló tényezők és a válaszadó önmagán megfigyelt változásainak kapcsolatát mutatja, korrelációs eljárást alkalmazva vizsgálva.

5. táblázat: A válaszadó életében bekövetkezett változások korrelációja a megtapasztalt, szolgálatellátást befolyásoló tényezőkkel $\left({ }^{*} p \leq 0,05 ;{ }^{* *} p \leq 0,01\right)$. Forrás: a szerző saját kutatása

\begin{tabular}{lccccccc}
\hline & \multicolumn{5}{c}{ Szolgálatellátást befolyásoló tényezók } \\
\cline { 2 - 7 } $\begin{array}{c}\text { Önmagán } \\
\text { megfigyelt } \\
\text { változások }\end{array}$ & $\begin{array}{c}\text { alvási } \\
\text { nehéz- } \\
\text { ségek }\end{array}$ & fáradtság & $\begin{array}{c}\text { ingerült- } \\
\text { ség, } \\
\text { feszült- } \\
\text { ség }\end{array}$ & $\begin{array}{c}\text { aggodal- } \\
\text { mak } \\
\text { a család } \\
\text { miatt }\end{array}$ & $\begin{array}{c}\text { állandóan } \\
\text { a vírus } \\
\text { körül forgó } \\
\text { gondondatok }\end{array}$ & $\begin{array}{c}\text { félelem } \\
\text { a fertö- } \\
\text { zötté } \\
\text { válástól }\end{array}$ & egyéb \\
\hline $\begin{array}{l}\text { alvási } \\
\text { nehézségeim } \\
\text { voltak }\end{array}$ &, $825^{* *}$ &, $393^{*}$ &, 345 &, 046 &, 219 &, 204 &, 211 \\
\hline $\begin{array}{l}\text { fáradékonyabb } \\
\text { lettem }\end{array}$ &, $518^{* *}$ &, $498^{* *}$ &, $668^{* *}$ &, 303 &, $425^{*}$ &, 077 &, $576^{*}$ \\
\hline
\end{tabular}




\begin{tabular}{|c|c|c|c|c|c|c|c|}
\hline \multirow[b]{2}{*}{$\begin{array}{l}\text { Önmagán } \\
\text { megfigyelt } \\
\text { változások }\end{array}$} & \multicolumn{7}{|c|}{ Szolgálatellátást befolyásoló tényezők } \\
\hline & $\begin{array}{l}\text { alvási } \\
\text { nehéz- } \\
\text { ségek }\end{array}$ & fáradtság & $\begin{array}{l}\text { ingerült- } \\
\text { ség, } \\
\text { feszült- } \\
\text { ség }\end{array}$ & $\begin{array}{l}\text { aggodal- } \\
\text { mak } \\
\text { a család } \\
\text { miatt }\end{array}$ & $\begin{array}{c}\text { állandóan } \\
\text { a vírus } \\
\text { körül forgó } \\
\text { gondolatok }\end{array}$ & $\begin{array}{c}\text { félelem } \\
\text { a fertő- } \\
\text { zöttté } \\
\text { válástól }\end{array}$ & egyéb \\
\hline $\begin{array}{l}\text { ingerültté, } \\
\text { feszültté váltam }\end{array}$ &, $545^{* *}$ &, $545^{* *}$ &, $738^{* *}$ & ,353 & ,361 & ,135 & ,349 \\
\hline $\begin{array}{l}\text { megváltozott } \\
\text { a viselkedésem } \\
\text { másokkal } \\
\text { szemben }\end{array}$ & ,135 & ,107 &, $508^{* *}$ & ,093 & ,210 &,- 025 &, $784^{* *}$ \\
\hline $\begin{array}{l}\text { türelmetlenebb } \\
\text { lettem }\end{array}$ & ,177 & ,243 &, $505^{* *}$ & ,112 & ,272 & ,075 & ,421 \\
\hline aggódtam &, 370 & , 452* &, $417^{*}$ & ,387* &, $579^{* *}$ & ,187 & ,211 \\
\hline $\begin{array}{l}\text { állandóan a vírus } \\
\text { körül forogtak } \\
\text { a gondolataim }\end{array}$ & ,127 & ,289 & ,362 & ,066 &, $786^{* *}$ & ,345 & ,491 \\
\hline
\end{tabular}

A fentebb ismertetett eredményeket jelen írás korlátainak szem előtt tartásával mutattam be a legalapvetőbb jellemzőkre koncentrálva, de a rendelkezésre álló csekély számú, nem reprezentatív minta ellenére is számos további elemzést végeztem el a rendelkezésre álló, mentális egészségi állapotra vonatkozó adatokon, amelyek szintén érdekesek lehetnek, ha szeretnénk jobban megérteni a pályafutásuk elején járó fiatal ôrmesterek járványhelyzethez való viszonyulását.

\section{Következtetések, észrevételek}

Összeségében elmondható, hogy a tavaszi időszakban a veszélyhelyzet megélése nem jelentett kiemelkedő pszichés megterhelést a vizsgálati mintában szereplők számára. Ugyanakkor a teljes próbaidős állományra nézve következtetéseket levonni az alacsony válaszadási hajlandóság miatt nem szerencsés, illetve mivel online tesztfelvétel történt, előfordulhat, hogy eleve a helyzetet kevésbé rosszul megélők vállalkoztak inkább a kérdőív kitöltésére.

Áttekintve a kapott eredményeket azt mondhatjuk, hogy a válaszadók döntő többsége a járványhelyzethez kapcsolódó többféle rendőri feladatban kipróbálhatta magát. Ez mindenképpen szerencsés abból a szempontból, hogy még szélesebb körü tapasztalatra tehettek szert a próbaidő alatt.

A félelmek tekintetében kapott összefüggések, kapcsolódási pontok mindenképpen rávilágítanak arra, hogy nem minden az, hogy átlagosan milyen mértékben félnek az egyes lehetőségektől a koronavírus-fertőzés kapcsán - az is érdekes és fontos lehet, hogy mennyire szorosak emberi kapcsolatai, s ezáltal mennyire nagy az esélye átadni a betegséget másoknak. Tekintettel arra, hogy a tavaszi időszakban az egyik legfontosabb tényező, amit a vírus terjedéséről tudtunk, az volt, hogy nagyon könynyen és gyorsan fertőz, és ellene a legjobb védekezés a társas távolság intézménye, 
illetve a rendőri tevékenységek többsége valamilyen kapcsolatban állt a karantén intézményével, ezek az eredmények összességében szintén nem meglepők.

Szintén természetes jelenség, hogy a nem megfelelő minőségű és/vagy mennyiségű alvás számos negatív hatással van mentális egészségünkre és viselkedésünkre: fáradtabbak leszünk, ezáltal ingerlékenyebbek, türelmetlenebbek, feszültebbek is. Éppen ezért az e tényezők közötti összefüggés mindkét kérdéskörben (mennyire vette észre magán ezeket a változásokat, illetve mennyire befolyásolták ezen tényezők a szolgálatellátást) várható volt. ${ }^{28}$

Grover és munkatársai hasonló kérdéseket is tartalmazó kutatása az indiai rendőrök körében az általam találtaknál jelentősen magasabb szintű érzelmi megterhelésről, félelmekről, ingerlékenységről, feszültségről számoltak be, ugyanakkor ennek több oka lehetséges: jelentősen magasabb mintaelemszám, jelentősen magasabb átlagéletkor mellett nem hanyagolhatjuk el azt a tényezőt sem, hogy Indiában már a tavaszi időszakban jelentősen erősebb volt a vírus jelenléte, mint hazánkban. ${ }^{29}$ Ezenkívül azonban hasonló tényezőket vizsgáló kutatási eredményeket még nem publikáltak jelen cikk írásáig.

Az egyes egészségmagatartási formák esetében az alkoholfogyasztás és dohányzás összekapcsolódása, illetve az edzés kapcsolata a táplálkozással természetes jelenségnek számítanak a vizsgált korosztály körében, amelyet az ebben az elemzésben találtak is megerősítettek.

Habár a kapott összefüggések a maguk nemében nem számítanak meglepőnek, mégis fontosak abból a szempontból, hogy valamelyest képet adnak a hazai próbaidős tiszthelyettesek veszélyhelyzet alatti életéről, egyes témakörök kapcsán megélt érzéseikről. Ezeken túlmenően az egyes kérdéscsoportok az eredeti kérdőívcsomag vonatkozó részeivel történő összevetése mindenképpen érdekes lehet a továbbiakban, mert irányt mutathat a mentális egészségi állapottal való összefüggések terén, továbbá a munkahelyi stresszel kapcsolatos tényezők és a koronavírus kapcsolatáról is segíthet képet alkotnunk, mint ahogyan az egészségmagatartási szokásokkal, vagy azok változásával kapcsolatban is.

A fentebb ismertetett vizsgálat emellett mindenképpen alapot jelent a további, koronavírus és mentális egészég összefüggéseit feltárni kívánó vizsgálat számára a rendőri állomány körében, mivel a felmérés a tavaszi időszakra vonatkozóan készült, a mérés időpontja jószerével a nyár eleji enyhülő szabályozásokkal is egybeesett, de ősszel sokan a saját bőrünkön érezhettük a vírus ismételt felerősödését hazánkban, ezáltal valószínűsíthető, hogy az ezen időszakra vonatkozó hasonló mérés ugyanezen minta körében meglehetősen más képet festene.

Fontos kiemelni, hogy a felmérés 2020. május végén - június elején történt, azaz az eredmények a március 11-től május elejéig tartó szolgálati időszakra vonatkoznak. Ekkoriban az első hullám zajlott hazánkban, amelynek során a megbetegedések

\footnotetext{
28 Grover et alii (2020b) i. m.

29 Grover et alii (2020b) i. m.
} 
száma jelentősen alacsonyabb volt, mint a második hullám idején, az ezt követő őszitéli időszakban, ugyanakkor a vírusról is jelentősen kevesebb információ állt rendelkezésünkre - azon túl, hogy rendkívül fertőző - a jelenlegiekhez képest. (S tagadhatatlan, hogy tudásbázisunk folyamatosan növekszik.) A próbaidős tiszthelyettesek esetében a járványhelyzet okozta változások a rendőri tevékenységben újdonságot jelentett, bizonyos esetekben olyan feladatokat vagy helyzeteket, amelyek nem feltétlenül szerepelnek a rendőrképzés tananyagában. Ezért mindenképpen érdemes volt a járvánnyal kapcsolatos kérdéseket beépíteni a kutatás utolsó mérési pontján, mert a kapott eredmények segíthetnek abban, hogy a jövőben milyen irányokban érdemes a pszichés felkészítést alakítani ezen a területen.

\section{IRODALOMJEGYZÉK}

Borbély Zsuzsanna: Az iskolarendszerű rendőrképzés napjainkban. In Zsámbokiné Ficskovszky Ágnes (szerk.): Biztonság, szolgáltatás, fejlesztés, avagy új irányok a bevételi hatóságok múködésében. Budapest, Magyar Rendészettudományi Társaság Vám- és Pénzügyőri Tagozat, 2019. 3851. Online: https://doi.org/10.37372/mrttvpt.2019.1.2

Farrow, Kathryn: Policing the pandemic in the UK using the principles of procedural justice. Policing: A Journal of Policy and Practice, 14. (2020), 3. 587-592. Online: https://doi.org/10.1093/ police/paaa031

Frenkel, Marie Ottilie - Laura Giessing - Sebastian Egger-Lamp - Vana Hutter - Raoul R. D. Oudejans - Lisanne Kleygrewe - Emma Jaspaert - Henning Plessner: The impact of the COVID-19 pandemic on European police officers: Stress, demands, and coping resources. Journal of Criminal Justice, 72. (2020), 1-14. Online: https://doi.org/10.1016/j.jcrimjus.2020.101756

Grover, Sandeep - Swapnajeet Sahoo - Devakshi Dua - Aseem Mehra - Ritu Nehra: Psychological impact of COVID-19 duties during lockdown on police personnel and their perception about the behavior of the people: An exploratory study from India. International Journal of Mental Health and Addiction, (2020a), 1-12. Online: https://doi.org/10.1007/s11469-020-00408-8

Grover, Sandeep - Swapnajeet Sahoo1 - Aseem Mehra1 - Ajit Avasthi - Adarsh Tripathi - Alka Subramanyan - Amrit Pattojoshi - G Prasad Rao - Gautam Saha - KK Mishra - Kaustav Chakraborty - Naren P Rao et alii: Psychological impact of COVID-19 lockdown: An online survey from India. Indian Journal of Psychiatry, 62. (2020b), 4. 354-362. Online: https://doi.org/10.4103/ psychiatry.IndianJPsychiatry_427_20

Jennings, Wesley G. - Nicholas M. Perez: The Immediate Impact of COVID-19 on law enforcement in the United States. American Journal of Criminal Justice, 45. (2020), 690-701. Online: https:// doi.org/10.1007/s12103-020-09536-2

Khadse, Pawab Arun - Guru S. Gowda - Sundarnag Ganjekar - Geetha Desai - Pratima Murthy: Mental health impact of COVID-19 on police personnel in India. Indian Journal of Psychological Medicine, 42. (2020), 6. 580-582. Online: https://doi.org/10.1177/0253717620963345

Laufs, Julian - Zohan Waseem: Policing in pandemics: A systematic review and best practices for police response to COVID-19. International Journal of Disaster Risk Reduction, 51. (2020), 1-17. Online: https://doi.org/10.1016/j.ijdrr.2020.101812

Stogner, John - Bryan Lee Miller - Kyle McLean: Police stress, mental health, and resiliency during the COVID-19 pandemic. American Journal of Criminal Justice, 45. (2020), 718-730. Online: https://doi.org/10.1007/s12103-020-09548-y

Soloviev, Andrey - Sergey Zhernov - Elena Ichitovkina: Female Moscow police officers' emotional reactions features during service in the COVID-19 pandemic emergency conditions. Journal 
of Biomedical Research \& Environmental Sciences, 1. (2020), 6. 213-215. Online: https://doi. org/10.37871/jbres1145

Vicario-Merino, Angel - Noemi Muñoz-Agustin: Analysis of the stress, anxiety and healthy habits in the Spanish COVID-19 confinement. Health Science Journal, 14. (2020), 2. 1-6. Online: https://doi.org/10.36648/1791-809X.14.2.707

Yuan, Lili - Lele Zhu - Fangfang Chen - Qian Cheng - Qian Yang - Zhiming Zhou Zhou - Yujuan Zhu - Yigao Wu - Yong Zhou - Xiaojuan Zha: A survey of psychological responses during the coronavirus disease 2019 (COVID-19) epidemic among Chinese police officers in Wuhu. Risk Management and Healthcare Policy, 13. (2020), 2689-2697. Online: https://doi.org/10.2147/ RMHP.S269886

\section{Jogi forrás}

41/2020. (III. 11.) Korm. rendelet az élet- és vagyonbiztonságot veszélyeztető tömeges megbetegedést okozó humánjárvány megelőzése, illetve következményeinek elhárítása, a magyar állampolgárok egészségének és életének megóvása érdekében elrendelt veszélyhelyzet során teendő intézkedésekről

\section{ABSTRACT}

\section{Experiences of Policing the Pandemic among Police Trainees}

\section{Zsuzsanna BORBÉLY}

The Covid-19 pandemic has started its conquering journey around the world. In view of this, we surveyed the experiences of the police trainees in the first two months of the pandemic in Hungary as part of an ongoing research in the 2019-2020 school year. They were members of different police departments, and the epidemic-related activities became part of their everyday tasks, so they had colourful experiences.

In the research we used a 14 question survey form compiled by us. The query happened online during the period of their professional examinations (the end of May - the beginning of June 2020); we got 28 answered questions about the experiences of policing the pandemic.

The results showed that the tasks were checking official home quarantine, duty at border crossing points and duty on public places related to the lockdown. The vast majority of the interviewed (85.7 per cent) did not feel these tasks emotionally overwhelming, while a little bigger part of them rated the duties physically overwhelming (28.6 per cent). We asked about their fears, too. The most intense fear was the infection of their family members, it was followed by infecting others and the infection of colleagues, but they did not feel intense fear about becoming infected.

Based on the results, we can probably say that the first two months of policing the pandemic did not mean extreme psychological overload. Although the results are not representative, they can be a starting point for further research of the theme - especially because the autumn pandemic is more stressful for everyone both psychologically and physically.

Keywords: Covid-19, emotionally overwhelming, police trainees 